\title{
Strategies on Teaching Reform of Advanced Mathematics from the Perspective of "MOOC"*
}

\author{
Jinling You \\ Heihe University \\ Heihe, China 164300
}

\author{
Xiaoyuan Luo \\ Heihe University \\ Heihe, China 164300
}

\begin{abstract}
MOOC" is a new development mode of online course. Its innovation and reform in teaching idea and teaching design have positive influence on information-based construction of advanced mathematics. From the perspective of "MOOC", main characteristics of MOOC are summarized and difference between the teaching model of "MOOC" and the traditional teaching model of advanced mathematics is analyzed, in order to propose strategies for teaching reform of advanced mathematics from teaching idea, curriculum provision and teaching contents.
\end{abstract}

Keywords-MOOC; advanced mathematics; teaching reform; strategies

\section{INTRODUCTION}

With rapid development of internet and popularization of electronic equipment, as a new development mode of online courses, MOOC appears in network platforms frequently and becomes popular among learners because of its unique openness and autonomy. Massive Open Online Courses is MOOC for short [1] and obviously different from the traditional network distance education. It has become one of the important ways for college students and social elites to absorb knowledge and broaden horizon. As one of the important basic courses in major of science and technology, advanced mathematics absorbs impacts of MOOC for traditional teaching idea. Therefore, it has distinctly important theoretical value and practical significance to promote information-based teaching reform of higher education through referring to the teaching model of MOOC.

\section{MAIN CHARACTERISTICS OF MOOC}

Depending on connectionism theory and network open pedagogy, MOOC has the same teaching process as traditional university course, in order to let beginners grow into senior professionals. It covers science and technology discipline, social sciences and humanities, neither providing credits nor awarding degrees. Most courses are open to the public for free. The unique teaching forms of MOOC contribute to the following characteristics:

\section{A. Large-scale Participants}

Resources of MOOC are released not by one person or one institution but by instructors and learners worldwide, referring

*Fund project: Task of Education Scientific Planning Office of Heilongjiang Province, Research on Information-based Teaching Model of Advanced Mathematics (GBC1213039). to audiovisual materials of network communication uploaded in order to research and discuss the same topic or theme.

\section{B. Affluent and Open Course Resources}

"Affluence" is caused by large-scale participants who release videos to extend their opinions on the same topic or theme. "Openness" is the primary characteristic of MOOC. [2] It perfectly embodies open, democratic and free academic spirit. It implies free sharing, reutilization, modification and transmission of course resources. MOOC can greatly satisfy learning desire of learners regardless of obvious regional, economic and cultural differences.

\section{Micro Course, Pertinent Contents and Diversified Methods}

Mainstream course resources depend on micro courses taught by outstanding teachers who roundly elaborate some knowledge point. The methods vary with each individual such as embedded simulation experiment operation and writing of procedure code. These micro courses have prominent key and difficult points and small cognitive load, having improved teaching quality and learning efficiency.

\section{Controllable Video Learning}

MOOC is released on MOOC platforms. Knowledge information is transferred to learners through online video playing. When watching videos, learners can control, pause and playback to explore and regain related contents.

\section{E. Have Ability of Big Data Analysis and Quality Evaluation}

With plentiful learning, visiting, collaborative communication, MOOC platform records real time mass data. Analysis and processing of big data through data mining technology can observe key knowledge points of advanced mathematics understood by students, and improve the accuracy of inspecting teaching effects. 


\section{COMPARISON BETWEEN TEACHING MODEL OF MOOC AND TRADITIONAL TEACHING MODEL OF ADVANCED MATHEMATICS}

\section{A. MOOC Teaching Breaks the Limitation of Higher Education on Learners}

Advanced mathematics course is provided in universities or junior colleges for those qualified after college entrance examination. The rising of MOOC breaks the "fence" of higher education. Learners can learn online courses of advanced mathematics from famous universities in the world whenever and wherever possible only with computer and internet and can get study certificate of famous universities after passing the tests.

\section{B. MOOC Transforms Teaching Methods of Advanced Mathematics}

Traditional teaching model of advanced mathematics is spoon-feeding and has great limitation in cultivating innovative and applied talents. Teachers are subjects of classroom teaching and students passively receive theoretical knowledge of higher education. Interaction between teachers and students and between students is limited by time and space. Teaching model of MOOC overcomes drawbacks of traditional teaching. Learners can actively watch video courses of the world's top professors without the limitation of time and place, and adjust to look back and understand difficult knowledge points. Meanwhile, consolidation and understanding of knowledge in advanced mathematics are strengthened through self-evaluation, mutual evaluation of learners and teachers' evaluation. It fully embodies students' dominant position, arouses their learning interests and better conforms to teaching law.

\section{MOOC Teaching Facilitates Individualized Teaching and Meets Requirements of Personality Cultivation}

MOOC teaching carries out intelligent technical analysis on big data information related to students' learning, letting education depend on data instead of experience. Reflecting students' learning situation through data helps teachers to monitor, trace and grasp students' learning schedule and judge their learning ability, and then propose effective suggestions, in order to realize individualized and differentiation development of students.

\section{STRATEGIES FOR TEACHING REFORM OF ADVANCED MATHEMATICS FROM THE PERSPECTIVE OF MOOC}

To cope with impact brought by MOOC, course reform of advanced mathematics will neither ignore nor passively participate, let alone bringing the original MOOC in class, because the three ways go against the training of applied talents in advanced mathematics and may lead to backward teaching quality. Therefore, attentions should be paid to the following aspects.

\section{A. Teaching Idea of Advanced Mathematics}

In the era of MOOC, network has become one of the main ways of students' cognition. Teachers are no longer the emission source of authoritative knowledge. Therefore, updating teaching idea of teachers of advanced mathematics becomes the primary task. First, teachers should recognize their position. They are not only knowledge transmitter but also assistant, guide and server of students, and should give up "dominant position" to students. Second, teachers should advocate students' diversified and personalized development. At present, some teachers still have traditional teaching idea that teaching is to teach students knowledge. Some teachers teach some computing methods but keep silent about practical application of knowledge. Some even think exam results are the sole criterion to check students' learning and reject those influence results. Without the idea of students' personalized cultivation, they kill students' development potential in many aspects, which go against students' growth. Last, teachers should establish the concept of lifelong learning. As guide of students, teachers must get rid of outdated educational concept and accept good things. From the perspective of MOOC, teachers must update teaching idea, learn modernized information technology and improve practical ability, in order to better adapt to MOOC era of advanced mathematics.

\section{B. Course Construction}

From the perspective of MOOC, course construction of advanced mathematics must meet employment demand and conform to industrial characteristics. First, the construction of teaching staff and the cultivation of "double-professionallytitled" teachers are strengthened. Second, attentions are paid to reform and innovation of teaching models and methods. Learn from strong points of MOOC and bring tests in teaching to timely grasp students' cognition. Third, network teaching platforms are constructed. Basic resources like teaching plan database, courseware database, video database and question bank of advanced mathematics are continuously improved to create conditions for students' autonomous learning. Four, textbook compilation should be strengthened. Textbooks that meet students' demands are compiled. Fifth, practical teaching is strengthened. Students' manipulative ability, innovation ability and entrepreneurial ability are continuously improved through participating in innovation projects and projects with university-enterprise cooperation. Sixth, scientific and reasonable assessment mode is established, and the proportion of practice assessment is increased.

\section{Teaching Contents}

Contents of MOOC center on core concepts in subject area. Teaching contents of each lesson only center on one definition or theorem [3]. Therefore, each less can be regarded as a micro knowledge point. Besides, sections of MOOC are closely connected and coherent. Learners can naturally connect these isolated micro knowledge points. Advanced mathematics is theoretical. Teachers can roundly consider students' cognition order and contents in each chapter and transform teaching contents into micro knowledge points. At the meantime, bring test problems between micro knowledge points to timely grasp students' understanding. Moreover, according to the design methods of MOOC teaching, teaching contents of advanced mathematics can be divided into parts in and after class. In class, the teacher teaches decomposed micro knowledge points. After class, teachers and students can discuss micro knowledge 
points through network teaching platforms, in order to improve teaching effects of advanced mathematics.

\section{CONCLUSION}

At present, increasingly attentions at home and abroad are paid to the construction of MOOC, which will accelerate the information-based reform of advanced mathematics. It is necessary to timely update teaching idea of teachers of advanced mathematics, strengthen the construction of advanced mathematics, accurately compact and reasonably arrange teaching contents to improve teaching level. Furthermore, information-based construction of advanced mathematics should be strengthened to provide colorful teaching resources for students and meet their demands in personalized development, meanwhile arouse their learning interests and improve their ability in solving problems through mathematical tools.

\section{REFERENCES}

[1] Guo Yingjian. Current Situation, Predicament and Future of "MOOC" [J], Journal of Higher Education Management, 2014, 04: 41-48

[2] Zhang Zhiyuan. Influence of "MOOCs" on Chinese Higher Education and Countermeasures $[\mathrm{J}]$, Hebei Normal University Journal (Education Science Edition), 2014, 02: 116-121

[3] Wu Weizhong, Guan Xiaohui, Qu Zhaoyang. Thinking on University Teaching Reform Caused by "MOOC" [J], Journal of Northeast Normal University (Philosophy and Social Science Edition), 2015, 02: 190-194

[4] Li Fei, Huang Mingdong. Opportunities and Challenges Brought by "MOOC" [J], China Higher Education, 2014, 07: 22-26 